\title{
FEM modelling of shoes insoles components for standing and walking simulation
}

\author{
Barbu Braun ${ }^{1, *}$, and Mihaela Baritz ${ }^{1}$ \\ ${ }^{1}$ Transilvania University of Brasov, Department of Product Design, Mechatronics and Environment, \\ Brasov, Romania
}

\begin{abstract}
The paper presents a research stage in which a new method applied for foot insoles components rapid prototyping was successfully tested in case of two young persons with small orthopaedic diseases. The research in this stage is focused on the FEA model analysis before and after prototyping, the model consisting in two sets of specific items to be inserted into the plantar supporters, with orthopaedic correction role. The simulation and testing was performed in condition of wearing shoes containing such of plantar supporters, when standing and walking, these situations being the most common. The main studied problem was to verify if the CAD modelled orthotic items to be prototyped should resist in case of static and dynamic loads, similar to those found in case of standing and walking. It was demonstrated a good correlation in terms of testing results before and after items prototyping, especially for the second person. Besides, it was demonstrated that the FEA analysis applied method could be successfully used to verify the prototyped orthotic items endurance and resistance.
\end{abstract}

\section{Role of shoes insoles for health and daily activities}

Walking and standing are activities that occur daily in your current life and as a result, wearing comfortable shoes and suitable is crucial. For this reason, the insoles play a keyrole. For this reason in recent years, research on foot insoles optimising in terms of design, especially the comfort, is in a continuous increase. Concretely, research has developed in three directions: to increase comfort when wearing different type of shoes, for daily activities, to increase athletic performance, to correct some foot malformation (flatfoot, Hallux, Valgus, pronounced arch) (especially for children) [1, 2], or to monitor and improve the health status.

The first direction addresses researches referring to new comfortable and biocompatible materials, to increase the degree of comfort when standing or walking [3,4].

Referring to the athletic performances, different sensory micro-systems encapsulated were developed to measure any body behaviour parameters (e.g. measuring the intensity of physical activity and connecting a piezoelectric film (inserted into the sole of a shoe) to a Blue tooth or Smart phone devices) $[5,6]$.

*Correspondng author: braun@unitbv.ro 
On the last aspect, in the last years there were developed different types of foot insoles, having the possibility to control and even to monitor the human body parameters (e.g. blood pressure, pulse), via pressure / force / acceleration sensors encapsulated [7].

\section{Insoles components rapid prototyping for any foot diseases}

The paper presents a stage of research on the modelling of shoe insoles components, for dedicated orthopaedic footwear in case of two persons with plantar diseases. The first one was identified with pronounced arch, and the second person was identified with flatfeet, low degree. For both persons it was took the problem to improve the shoes, in order to correct more efficiently and easily the feet deformities. Thus means that for each one, a pair of foot insoles including orthotic elements was manufactured. The research is about the stage in which the orthotic items, corrective role were modelled and prototyped. For this reason, five steps were established: CAD modelling of the plantar corrective items [8], simulation using finite element analysis (FEA) of the CAD modelled items (virtual model), items rapid prototyping, foot insoles manufacturing, including the prototyped corrective items [9] and FEA of the prototyped items (as demonstrative model) to demonstrate their endurance and strength during walking and standing.

\subsection{CAD modelling of the orthotic corrective items}

For both persons, for CAD modelling, it was started from the scanning procedure applied for two pair of mouldings, representing the feet conformation [8]. For this reason, the prototyping items were modelled having the foot sole CAD model as reference surface, the final model being generated by applying successive specific operations, using CATIA V5 software environment. In Fig. 1 there are presented some CAD models specific to prototyping items:

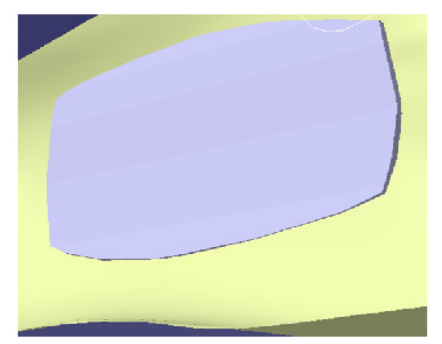

Fig. 1. Example of CAD modelling for a prototyping item specific to insoles for flatfeet correction

Respecting the same procedure, there were generated the CAD models specific to insoles for pronounced arch correction (the second case).

The next step necessary for foot insoles manufacturing was to prototype the CAD modelled items, specific to both cases. To ensure that these would resist to static and dynamic loads (corresponding to daily activities - standing, walking) when manufactured foot insoles wearing, a simulation test, using FEA, for each CAD modelled item was performed. It was taken into account that the material for items prototyping is considered to be the ABS plastic. In order to simulate the behaviour, the Poisson coefficient specific to the material was known $(v=0.33)$, and the acting loads were determined, taking into account the body weight. The CAD models allowed measuring the prototyping models dimension, thus allowing determining the items surfaces reported to the foot sole area. Knowing the investigated person's body weight, the assigned load to the items could be estimated, using the relations (1) and (2): 


$$
F_{s}=\frac{m \cdot g}{2} \cdot \frac{A_{i}}{A_{f_{-} s}}
$$

where: $\mathrm{F}_{\mathrm{s}}[\mathrm{N}]$ - acting load when standing (in static mode); $\mathrm{m}[\mathrm{kg}]$ - body weight; $\mathrm{g}\left[\mathrm{m} / \mathrm{s}^{2}\right]$ - gravitational acceleration; $A_{i}$ - surface area for the modeled item; $A_{f_{-} s}$ - surface area for the entire foot sole;

$$
F_{d}=\frac{m \cdot g}{2} \cdot \frac{A_{i}}{A_{f_{-} s}} \cdot \Psi
$$

where: $\mathrm{F}_{\mathrm{d}}[\mathrm{N}]$ - load when walking (in dynamic mode); $\Psi$ - dynamic coefficient correlation (experimentally estimated to be about $2.2 \div 2.4$ ).

For the first person, having plantar pronounced arch, in terms of foot insoles, it was necessary to prototype two items to be encapsulated into the insoles, to correct the disease: the first one being specific to the heel area and the second corresponding to the metatarsal area. Knowing that its body weight is about $71 \mathrm{~kg}$, it was proceeded to determine the estimative compression loads for both prototyping items, using the relations (1) and (2).

In case of the second person, with flatfeet, low degree, in terms of foot insoles, it was necessary to prototype one item, specific to the median foot area, for plantar correction. Using the relations (1) and (2) and knowing that his body weight is about $59 \mathrm{~kg}$, it was proceeded to determine the estimative compression load for the prototyping item, also.

Once obtained the CAD models for the prototyping items, for both tested persons, these were converted into .IGS files and imported into ANSYS software environment for FEA analysis (Fig. 2).

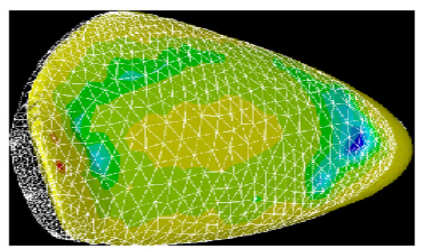

Fig. 2. Example of FEA in ANSYS for a CAD model, specific to the foot sole median area, to correct the flatfoot in case of the second person.

Fig. 2 presents an example of a prototyping item deformation, by FEA simulation. It can be observed also the stress distribution stress due to the compression load. The FEA results in terms of loads, strengths and deformations for prototyping items, in static and dynamic modes are presented in tables $1 \div 4$.

Table 1. FEA results for prototyping items, due to simulation in ANSYS of the CAD models for the

\begin{tabular}{|c|c|c|c|c|c|c|}
\hline & $\begin{array}{c}\text { Prototyping } \\
\text { element specific } \\
\text { to the plantar } \\
\text { area }\end{array}$ & $\begin{array}{c}\text { Calculated } \\
\text { load acting } \\
\text { on the } \\
\text { prototyping } \\
\text { item }(\mathrm{F})[\mathrm{N}]\end{array}$ & $\begin{array}{l}\text { Determined } \\
\text { strength } \\
(\sigma)[\mathrm{MPa}]\end{array}$ & $\begin{array}{c}\text { Maximum } \\
\text { admissible } \\
\text { strength } \\
\left(\sigma_{\mathrm{a}}\right) \\
{[\mathrm{MPa}]}\end{array}$ & $\begin{array}{l}\text { Determined } \\
\text { deformation } \\
\text { (f) }[\mathrm{mm}]\end{array}$ & $\begin{array}{r}\text { Maximum } \\
\text { admissible } \\
\text { deformation } \\
\left(f_{\max }\right)[\mathrm{mm}]\end{array}$ \\
\hline for & for heel area & 38.59 & \multirow{2}{*}{0.0257} & \multirow{4}{*}{60} & $0.7410^{-5}$ & \multirow{4}{*}{0.0016} \\
\hline $\begin{array}{l}\text { left } \\
\text { foot }\end{array}$ & $\begin{array}{c}\text { for metatarsal } \\
\text { area }\end{array}$ & 51.46 & & & $0.5510^{-5}$ & \\
\hline \multirow{2}{*}{$\begin{array}{l}\text { for } \\
\text { right } \\
\text { foot }\end{array}$} & for heel area & 38.21 & \multirow[b]{2}{*}{0.03} & & $0.810^{-5}$ & \\
\hline & $\begin{array}{c}\text { for metatarsal } \\
\text { area }\end{array}$ & 50.95 & & & $1.1 \quad 10^{-5}$ & \\
\hline
\end{tabular}
first person (with plantar pronounced arch), in case of standing (static mode). 
Table 2. FEA results for prototyping items, due to simulation in ANSYS of the CAD models for the first person (with plantar pronounced arch), in case of walking (dynamic mode).

\begin{tabular}{|c|c|c|c|c|c|}
\hline $\begin{array}{l}\text { Prototyping } \\
\text { element specific } \\
\text { to the plantar are }\end{array}$ & $\begin{array}{c}\text { Calculated } \\
\text { load acting on } \\
\text { the } \\
\text { prototyping } \\
\text { item }(\mathrm{F})[\mathrm{N}]\end{array}$ & $\begin{array}{l}\text { Determined } \\
\text { strength } \\
(\sigma)[\mathrm{MPa}]\end{array}$ & $\begin{array}{l}\text { Maximum } \\
\text { admissible } \\
\text { strength } \\
\left(\sigma_{\mathrm{a}}\right)[\mathrm{MPa}]\end{array}$ & $\begin{array}{l}\text { Determined } \\
\text { deformation } \\
\text { (f) }[\mathrm{mm}]\end{array}$ & $\begin{array}{c}\text { Maximum } \\
\text { admissible } \\
\text { deformation } \\
\left(\mathrm{f}_{\max }\right)[\mathrm{mm}]\end{array}$ \\
\hline \multicolumn{6}{|c|}{ for left foot } \\
\hline for heel area & 88.76 & 0.059 & \multirow[b]{2}{*}{60} & $1.7110^{-5}$ & \multirow[b]{2}{*}{0.0016} \\
\hline $\begin{array}{c}\text { for metatarsal } \\
\text { area }\end{array}$ & 72.04 & 0.036 & & $1.2510^{-5}$ & \\
\hline \multicolumn{6}{|c|}{ for right foot } \\
\hline for heel area & 87.89 & 0.06 & \multirow[b]{2}{*}{60} & $1.710^{-5}$ & \multirow[b]{2}{*}{0.0016} \\
\hline $\begin{array}{c}\text { for metatarsal } \\
\text { area }\end{array}$ & 71.33 & 0.0357 & & $1.2410^{-5}$ & \\
\hline
\end{tabular}

Table 3. FEA results for prototyping items, due to simulation in ANSYS of the CAD models for the second person (with flatfeet, low degree), in case of standing (static mode).

\begin{tabular}{|c|c|c|c|c|c|}
\hline $\begin{array}{c}\text { Prototyping } \\
\text { element specific } \\
\text { to the plantar area }\end{array}$ & $\begin{array}{c}\text { Calculated } \\
\text { load acting on } \\
\text { the } \\
\text { prototyping } \\
\text { item }(\mathrm{F})[\mathrm{N}]\end{array}$ & $\begin{array}{c}\text { Determined } \\
\text { strength } \\
(\sigma)[\mathrm{MPa}]\end{array}$ & $\begin{array}{c}\text { Maximum } \\
\text { admissible } \\
\text { strength } \\
\left(\sigma_{\mathrm{a}}\right)[\mathrm{MPa}]\end{array}$ & $\begin{array}{c}\text { Determined } \\
\text { deformation } \\
(\mathrm{f})[\mathrm{mm}]\end{array}$ & $\begin{array}{c}\text { Maximum } \\
\text { admissible } \\
\text { deformation } \\
\left(\mathrm{f}_{\max }\right)[\mathrm{mm}]\end{array}$ \\
\hline \multicolumn{7}{|c|}{ for left foot } \\
\hline for arch sole & 120.83 & 0.02 & 60 & $2.410^{-5}$ & 0.00161 \\
\hline \multicolumn{7}{|c|}{ for right foot } \\
\hline for arch sole & 116.18 & 0.02 & 60 & $2.310^{-5}$ & 0.0016 \\
\hline
\end{tabular}

Table 4. FEA results for prototyping items, due to simulation in ANSYS of the CAD models for the second person (with flatfeet, low degree), in case of walking (dynamic mode).

\begin{tabular}{|c|c|c|c|c|c|}
\hline $\begin{array}{c}\text { Prototyping } \\
\text { element specific } \\
\text { to the plantar area }\end{array}$ & $\begin{array}{c}\text { Calculated } \\
\text { load acting on } \\
\text { the } \\
\text { prototyping } \\
\text { item }(\mathrm{F})[\mathrm{N}]\end{array}$ & $\begin{array}{c}\text { Determined } \\
\text { strength } \\
(\sigma)[\mathrm{MPa}]\end{array}$ & $\begin{array}{c}\text { Maximum } \\
\text { admissible } \\
\text { strength } \\
\left(\sigma_{\mathrm{a}}\right)[\mathrm{MPa}]\end{array}$ & $\begin{array}{c}\text { Determined } \\
\text { deformation } \\
(\mathrm{f})[\mathrm{mm}]\end{array}$ & $\begin{array}{c}\text { Maximum } \\
\text { admissible } \\
\text { deformation } \\
\left(\mathrm{f}_{\max }\right)[\mathrm{mm}]\end{array}$ \\
\hline \multicolumn{7}{|c|}{ for left foot } \\
\hline for arch sole & 205.41 & 0.04 & 60 & $410^{-5}$ & 0.00163 \\
\hline \multicolumn{7}{|c|}{ for right foot } \\
\hline for arch sole & 199.47 & 0.04 & 60 & $3.910^{-5}$ & 0.00162 \\
\hline
\end{tabular}

\subsection{Foot insoles manufacturing}

The results on FEA analysis of the items CAD models leaded to the information that their behaviour in case in which these will be prototyped and inserted into the orthopaedic foot insoles would be appropriate in terms of endurance and resistance when standing and walking. As a result, the next step was to perform the rapid prototyping of the concerned items, by converting the CAD models as .IGS files into .STL files. For this operation there it was used a 3D printing, in ABS plastic and special printing support, by importing the 
.STL files into the CatalystEX software environment associated to the 3D Printer. In Fig. 3 there are presented some examples of prototyped orthotic items to be inserted into the foot insoles.

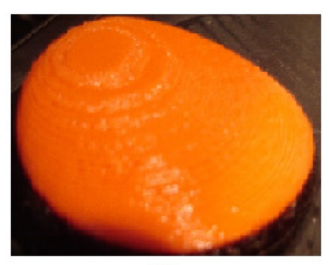

a)

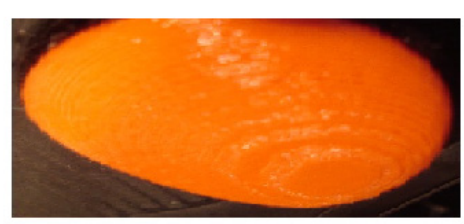

b)

Fig. 3. Example of prototyped orthotic items for heel area (a) and for metatarsal area (b), for inserting into the foot insoles to correct the pronounced arch in case of the first person.

The next step was to insert the prototyped items into the foot soles, using different insoles covers made of biocompatible and conformable materials, to ensure the comfort when wearing (Fig. 4).

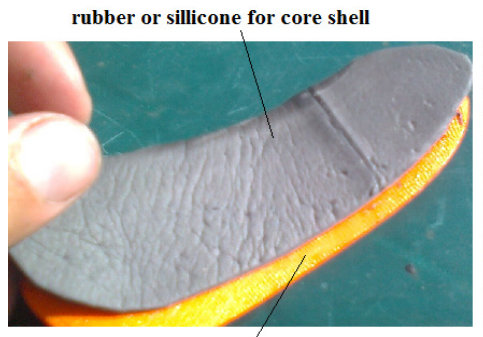

soft and antiperspirant cover for outside insoles

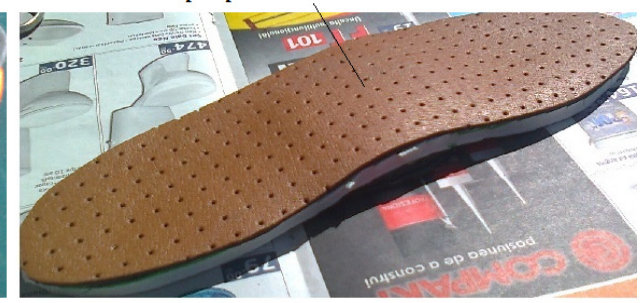

ABS plastic for insoles core

Fig. 4 The used materials for manufacturing the plantar insole for flatfoot progressive correction.

\section{FEA of the prototyped insoles items}

To complete the study on the prototyped items endurance and resistance, these were tested for the second time, this time in real condition, respectively when wearing the foot insoles during standing and walking. In this order, it was proceeded to measure in real time (by wearing the foot insoles) the plantar pressures, using a Foot Scan plate (equipped with 65,536 piezoelectric sensors), for both persons. The procedure was applied both in case of standing and walking on the force plate. Endurance and resistance of the inserted prototyped items invoked several steps: first of all the pressure distribution charts (Fig. 5 and 6) were done for both tested persons, left and right feet, when standing and when walking. Based on pressure distribution charts, the next step was to determine the averaged plantar pressures for areas of interest. It is about the heel and metatarsal area (addressed by the prototyping items) in case of the first person (with pronounced arch sole) and also the median area in case of the second person (with flatfeet, low degree). Then, knowing the mean pressure values and also the dimensions of the prototyped items, it was simple to determine the real loads acting on the orthotic items, when standing $\left(\mathrm{F}_{\mathrm{s}}\right)$ and when walking $\left(\mathrm{F}_{\mathrm{d}}\right)$ (relations 3).

$$
F_{s}=p_{i} \cdot A_{i} \text { and } F_{d}=p_{i} \cdot A_{i} \cdot \Psi
$$

where $p_{i}$ represents the mean pressure acting on the prototyped item (determined due to the plantar pressure charts), $A_{i}$ - the surface area of the prototyped items and $\Psi$ - multiplier impact coefficient $(\Psi>1)$, due to the dynamic shock, given by the energy conservation law: 


$$
\Psi=\sqrt{\frac{H}{f_{s}}}
$$

where $\mathrm{H}$ is the height from which the person stepping while walking and $f_{s}$ is the prototyping item deformation if standing (in static mode). Experimentally it could be determined the height $\mathrm{H}$ in case of both tested persons.

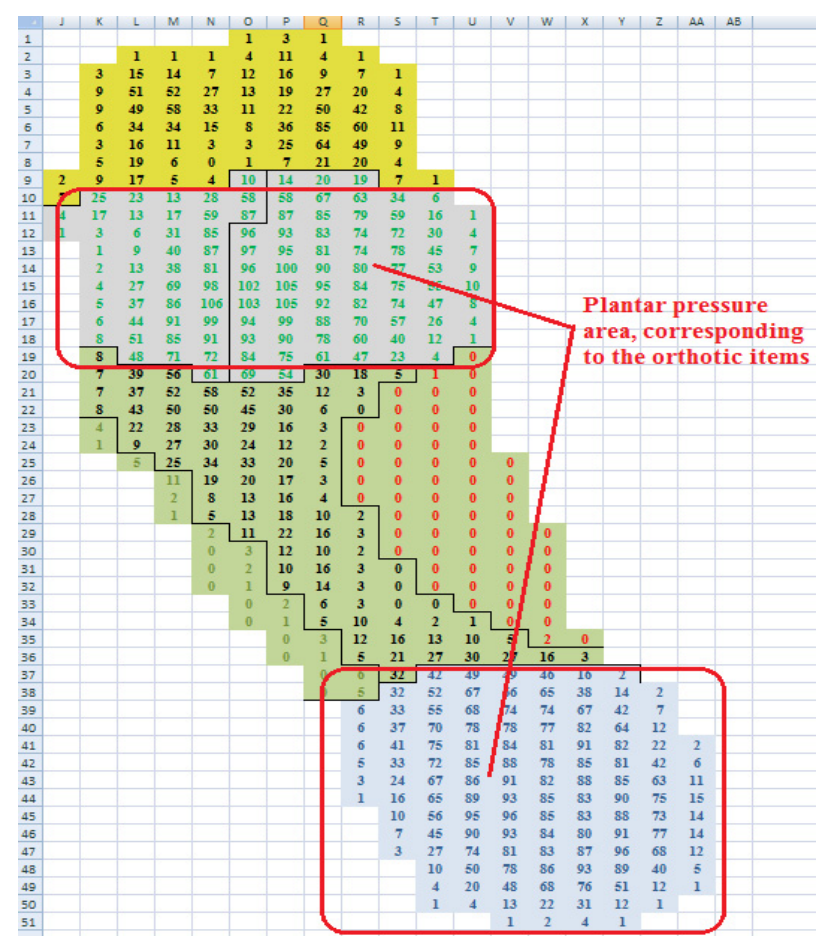

Fig. 5. Plantar pressures chart distribution for the left foot in the case of the first person (pronounced arch), tested when standing.

Table 5. FEA results, by using ANSYS, for the first tested person (with plantar pronounced arch), in case of standing (static mode) and wearing foot insoles including the prototyped orthotic items.

\begin{tabular}{|c|c|c|c|c|c|}
\hline $\begin{array}{l}\text { Prototyping } \\
\text { element specific } \\
\text { to the plantar area }\end{array}$ & $\begin{array}{c}\text { Calculated } \\
\text { load acting on } \\
\text { the } \\
\text { prototyping } \\
\text { item }(\mathrm{F})[\mathrm{N}]\end{array}$ & $\begin{array}{c}\text { Determined } \\
\text { strength } \\
(\sigma)[\mathrm{MPa}]\end{array}$ & $\begin{array}{l}\text { Maximum } \\
\text { admissible } \\
\text { strength } \\
\left(\sigma_{\mathrm{a}}\right)[\mathrm{MPa}]\end{array}$ & $\begin{array}{l}\text { Determined } \\
\text { deformation } \\
\text { (f) }[\mathrm{mm}]\end{array}$ & $\begin{array}{l}\text { Maximum } \\
\text { admissible } \\
\text { deformation } \\
\left(f_{\max }\right)[\mathrm{mm}]\end{array}$ \\
\hline \multicolumn{6}{|c|}{ for left foot } \\
\hline for heel area & 59.04 & \multirow[b]{2}{*}{0.04} & \multirow[b]{2}{*}{60} & $0.910^{-5}$ & \multirow[b]{2}{*}{0.0016} \\
\hline $\begin{array}{c}\text { for metatarsal } \\
\text { area }\end{array}$ & 83.84 & & & $1.310^{-5}$ & \\
\hline \multicolumn{6}{|c|}{ for right foot } \\
\hline for heel area & 51.16 & 0.03 & \multirow[b]{2}{*}{60} & $0.810^{-5}$ & \multirow[b]{2}{*}{0.0016} \\
\hline $\begin{array}{c}\text { for metatarsal } \\
\text { area }\end{array}$ & 88.62 & 0.05 & & $1.410^{-5}$ & \\
\hline
\end{tabular}




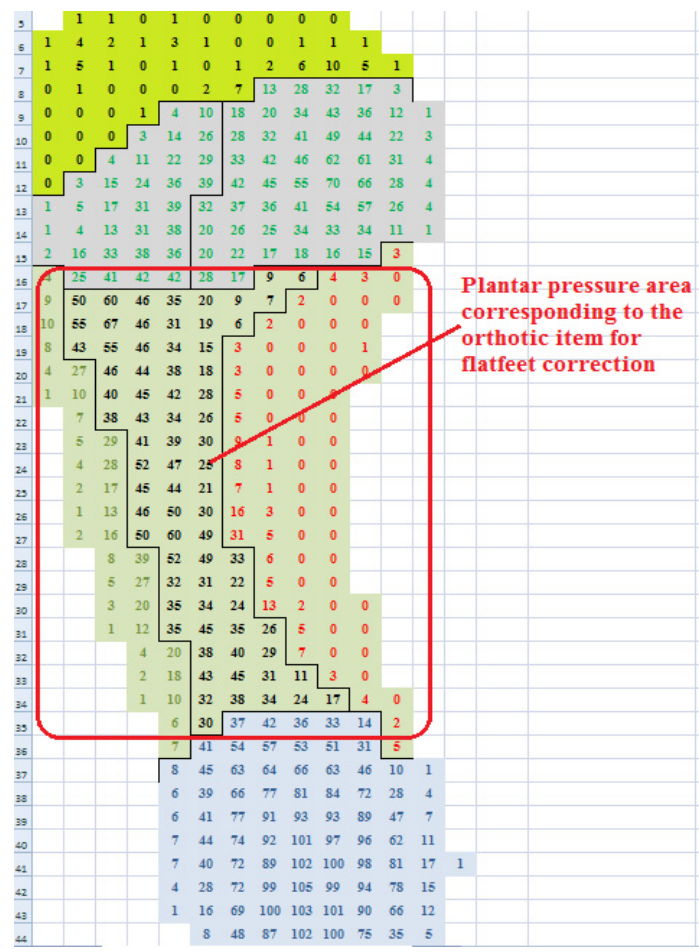

Fig. 6. Plantar pressures chart distribution for the left foot in the case of the second person (flat feet), tested when standing.

In this context, the FEA for the prototyped orthotic items was performed similarly to the FEA for the CAD modelled orthotic items, the results in terms of loads, strength and deformation being presented in the tables $5 \div 8$.

Table 6. FEA results, by using ANSYS, for the first tested person (with plantar pronounced arch), in case of walking (dynamic mode) and wearing foot insoles including the prototyped orthotic items.

\begin{tabular}{|c|c|c|c|c|c|}
\hline $\begin{array}{c}\text { Prototyping } \\
\text { element specific } \\
\text { to the plantar area }\end{array}$ & $\begin{array}{c}\text { Calculated } \\
\text { load acting on } \\
\text { the } \\
\text { prototyping } \\
\text { item }(\mathrm{F})[\mathrm{N}]\end{array}$ & $\begin{array}{l}\text { Determined } \\
\text { strength } \\
(\sigma)[\mathrm{MPa}]\end{array}$ & $\begin{array}{l}\text { Maximum } \\
\text { admissible } \\
\text { strength } \\
\left(\sigma_{\mathrm{a}}\right)[\mathrm{MPa}]\end{array}$ & $\begin{array}{l}\text { Determined } \\
\text { deformation } \\
\text { (f) }[\mathrm{mm}]\end{array}$ & $\begin{array}{l}\text { Maximum } \\
\text { admissible } \\
\text { deformation } \\
\left(f_{\max }\right)[\mathrm{mm}]\end{array}$ \\
\hline \multicolumn{6}{|c|}{ for left foot } \\
\hline for heel area & 112.14 & 0.07 & \multirow[b]{2}{*}{60} & $1.710^{-5}$ & \multirow[b]{2}{*}{0.0016} \\
\hline $\begin{array}{c}\text { for metatarsal } \\
\text { area }\end{array}$ & 116.92 & 0.06 & & $1.810^{-5}$ & \\
\hline \multicolumn{6}{|c|}{ for right foot } \\
\hline for heel area & 120.76 & 0.08 & \multirow[b]{2}{*}{60} & $1.910^{-5}$ & \multirow[b]{2}{*}{0.0016} \\
\hline $\begin{array}{c}\text { for metatarsal } \\
\text { area }\end{array}$ & 102.96 & 0.05 & & $1.610^{-5}$ & \\
\hline
\end{tabular}


Table 7. FEA results, by using ANSYS, for the second tested person (with flat feet, low degree), in case of standing (static mode) and wearing foot insoles including the prototyped orthotic items.

\begin{tabular}{|c|c|c|c|c|c|}
\hline $\begin{array}{c}\text { Prototyping } \\
\text { element specific } \\
\text { to the plantar area }\end{array}$ & $\begin{array}{c}\text { Calculated } \\
\text { load acting on } \\
\text { the } \\
\text { prototyping } \\
\text { item }(\mathrm{F})[\mathrm{N}]\end{array}$ & $\begin{array}{c}\text { Determined } \\
\text { strength } \\
(\sigma)[\mathrm{MPa}]\end{array}$ & $\begin{array}{c}\text { Maximum } \\
\text { admissible } \\
\text { strength } \\
\left(\sigma_{\mathrm{a}}\right)[\mathrm{MPa}]\end{array}$ & $\begin{array}{c}\text { Determined } \\
\text { deformation } \\
(\mathrm{f})[\mathrm{mm}]\end{array}$ & $\begin{array}{c}\text { Maximum } \\
\text { admissible } \\
\text { deformation } \\
\left(\mathrm{f}_{\max }\right)[\mathrm{mm}]\end{array}$ \\
\hline \multicolumn{7}{|c|}{ for left foot } \\
\hline for arch sole & 148.85 & 0.03 & 60 & $2.910^{-5}$ & 0.00163 \\
\hline \multicolumn{7}{|c|}{ for right foot } \\
\hline for arch sole & 132.53 & 0.02 & 60 & $2.610^{-5}$ & 0.00164 \\
\hline
\end{tabular}

Table 8. FEA results, by using ANSYS, for the second tested person (with flat feet, low degree), in case of walking (dynamic mode) and wearing foot insoles including the prototyped orthotic items.

\begin{tabular}{|c|c|c|c|c|c|}
\hline $\begin{array}{c}\text { Prototyping } \\
\text { element specific } \\
\text { to the plantar area }\end{array}$ & $\begin{array}{c}\text { Calculated } \\
\text { load acting on } \\
\text { the } \\
\text { prototyping } \\
\text { item (F) }[\mathrm{N}]\end{array}$ & $\begin{array}{c}\text { Determined } \\
\text { strength } \\
(\sigma)[\mathrm{MPa}]\end{array}$ & $\begin{array}{c}\text { Maximum } \\
\text { admissible } \\
\text { strength } \\
\left(\sigma_{\mathrm{a}}\right)[\mathrm{MPa}]\end{array}$ & $\begin{array}{c}\text { Determined } \\
\text { deformation } \\
(\mathrm{f})[\mathrm{mm}]\end{array}$ & $\begin{array}{c}\text { Maximum } \\
\text { admissible } \\
\text { deformation } \\
\left(\mathrm{f}_{\max }\right)[\mathrm{mm}]\end{array}$ \\
\hline \multicolumn{7}{|c|}{ for left foot } \\
\hline for arch sole & 237.15 & 0.04 & 60 & $4.710^{-5}$ & 0.00164 \\
\hline \multicolumn{7}{|c|}{ for right foot } \\
\hline for arch sole & 228.58 & 0.04 & 60 & $4.510^{-5}$ & 0.00163 \\
\hline
\end{tabular}

\section{Results and discussion}

A very important aspect of the research related to the orthotic items prototyping was to verify the FEA results by CAD models simulation with the FEA results based on real information when wearing the foot insoles. For this reason it was considered to compare results obtained in ANSYS before prototyping (by estimating the loads distribution) with the results obtained in ANSYS after prototyping (due to the information related to the plantar pressure charts).

Fig. 7 and 8 present the correlation diagrams in terms of prototyped orthotic items deformation, before and after manufacturing:

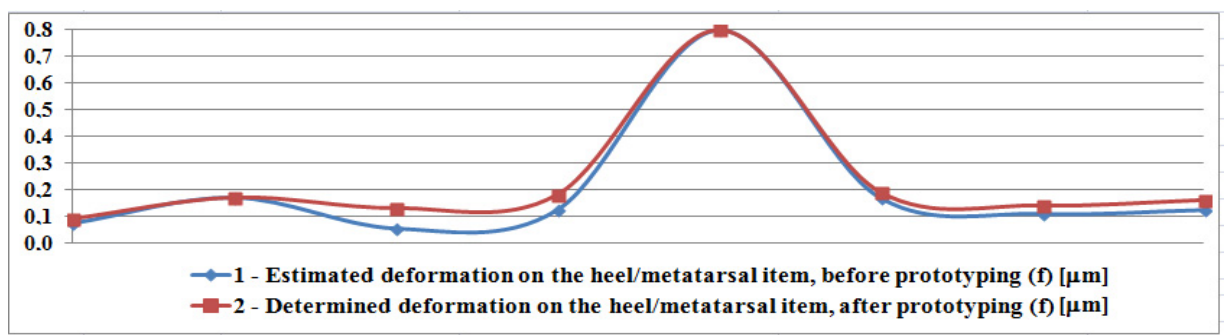

Fig. 7. Correlation diagrams on the results in terms of prototyped orthotic items for the foot insoles in case of the first person (with pronounced arch). 


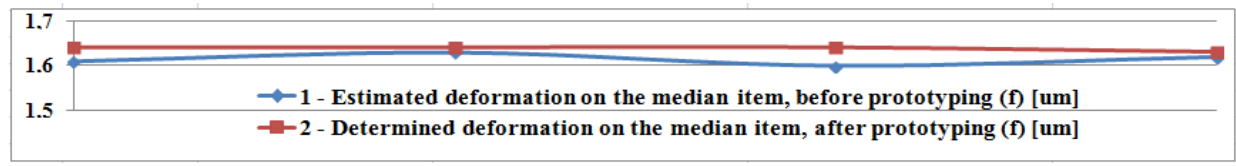

Fig. 8. Correlation diagrams on the results in terms of prototyped orthotic items for the foot insoles in case of the second person (with flatfeet, low degree).

Table 9. Results correlation in terms of prototyped orthotic items in case of the $1^{\text {st }}$ person.

\begin{tabular}{|c|c|c|c|c|}
\hline \multirow{2}{*}{\multicolumn{2}{|c|}{ Testing step }} & Before prototyping & After prototyping & \multirow{2}{*}{$\begin{array}{c}\text { Correlation in } \\
\text { terms of items } \\
\text { deformation } \\
{[\%]}\end{array}$} \\
\hline & & $\begin{array}{l}\text { Estimated deformation } \\
\text { on the item, before } \\
\text { prototyping (f) }[\mu \mathrm{m}]\end{array}$ & $\begin{array}{c}\text { Determined deformation } \\
\text { on the item, after } \\
\text { prototyping }(\mathrm{f})[\mu \mathrm{m}]\end{array}$ & \\
\hline \multicolumn{5}{|c|}{ Left foot } \\
\hline \multirow{2}{*}{$\begin{array}{c}\text { for heel } \\
\text { area }\end{array}$} & $\begin{array}{c}\text { when } \\
\text { standing }\end{array}$ & 0.074 & 0.09 & 17.78 \\
\hline & $\begin{array}{c}\text { when } \\
\text { walking }\end{array}$ & 0.171 & 0.17 & 0.59 \\
\hline \multirow{2}{*}{$\begin{array}{c}\text { for } \\
\text { metatarsal } \\
\text { area }\end{array}$} & $\begin{array}{c}\text { when } \\
\text { standing }\end{array}$ & 0.055 & 0.13 & 57.69 \\
\hline & $\begin{array}{c}\text { when } \\
\text { walking }\end{array}$ & 0.124 & 0.18 & 31.11 \\
\hline \multicolumn{5}{|c|}{ Right foot } \\
\hline \multirow[t]{2}{*}{$\begin{array}{l}\text { for heel } \\
\text { area }\end{array}$} & $\begin{array}{c}\text { when } \\
\text { standing }\end{array}$ & 0.8 & 0.8 & 0.00 \\
\hline & $\begin{array}{c}\text { when } \\
\text { walking }\end{array}$ & 0.17 & 0.19 & 10.53 \\
\hline \multirow{2}{*}{$\begin{array}{c}\text { for } \\
\text { metatarsal } \\
\text { area }\end{array}$} & $\begin{array}{c}\text { when } \\
\text { standing }\end{array}$ & 0.11 & 0.14 & 21.43 \\
\hline & $\begin{array}{c}\text { when } \\
\text { walking }\end{array}$ & 0.124 & 0.16 & 22.5 \\
\hline
\end{tabular}

Table 10. Results correlation in terms of prototyped orthotic items in case of the $2^{\text {nd }}$ person.

\begin{tabular}{|c|c|c|c|c|}
\hline \multirow{2}{*}{\multicolumn{2}{|c|}{ Testing step }} & Before prototyping & After prototyping & \multirow{2}{*}{$\begin{array}{c}\text { Correlation in } \\
\text { terms of items } \\
\text { deformation } \\
{[\%]}\end{array}$} \\
\hline & & $\begin{array}{l}\text { Estimated deformation } \\
\text { on the item, before } \\
\text { prototyping (f) }[\mu \mathrm{m}]\end{array}$ & $\begin{array}{c}\text { Determined deformation } \\
\text { on the item,after } \\
\text { prototyping }(\mathrm{f})[\mu \mathrm{m}]\end{array}$ & \\
\hline \multicolumn{5}{|c|}{ Left foot } \\
\hline \multirow{2}{*}{$\begin{array}{c}\text { for arch } \\
\text { sole }\end{array}$} & $\begin{array}{c}\text { when } \\
\text { standing }\end{array}$ & 1.61 & 1.64 & 1.83 \\
\hline & $\begin{array}{c}\text { when } \\
\text { walking }\end{array}$ & 1.63 & 1.64 & 0.61 \\
\hline \multicolumn{5}{|c|}{ Right foot } \\
\hline \multirow{2}{*}{$\begin{array}{c}\text { for arch } \\
\text { sole }\end{array}$} & $\begin{array}{c}\text { when } \\
\text { standing }\end{array}$ & 1.6 & 1.64 & 2.44 \\
\hline & $\begin{array}{c}\text { when } \\
\text { walking }\end{array}$ & 1.62 & 1.63 & 0.61 \\
\hline
\end{tabular}


In the tables 9 and 10 there are presented all information on correlation between estimated results and obtained results in real conditions, in terms of prototyped orthotic items deformation:

It was observed that for the first person, the correlation deviation was greater than in case of the second one. This could be explained through the fact that in case of the second person the flatfeet degree is less than the pronounced arch in case of the first person. In both cases the correlation deviation indicated that the determined loads acting on the orthotic items due to the foot insoles testing by their wearing were slightly higher than the estimative determined loads in the stage of their CAD modelling. However, even in this case it was found that the prototyped items should resist without any problem in any situation regarding the plantar supporters wearing when walking or standing, for both persons. Moreover, the orthotic items should resist even in case of their wearing (inside plantar supporters) by persons weighing up to about $120 \mathrm{~kg}$.

The presented method applied for plantar supporters manufacturing for the two presented cases proved to be very useful and efficient. Wearing the foot insoles by the two persons helped them to improve their walking and postural position reducing the problem regarding the hip, knees or ankle joints overloading. As a result, the undertaken researches in case of the two persons could be successfully applied in the future different persons (different age groups) with other plantar diseases (Hallux, Valgus etc.) or other orthopaedic diseases.

The research was supported by the Sector/Operational Program Human Resources Development (SOP HRD), ID 59323, financed from the European Social Fund and by the Romanian Government under the project number POSTDRU/89/1.5/S/59323.

\section{References}

1. A. Panjan, N. Sarabon, Methods for the Evaluation of Human Balance Body, Sport Sci Rev, XIX, 5-6 (2010)

2. V. Papilian, Anatomia omului (Pub H BIC ALL, Bucharest, 1998)

3. J. W. Brodsky, J. Brajtbord, S. C. Coleman, S. Raut, F. E. Polo, Effect of heating on the mechanical properties of insole materials, Foot Ankle Int 33, 772-778 (2012)

4. D. Mihov, B. Katerska, Some biocompatible materials used in medical practice, Trakia J of Sci 8, 119-125 (2010)

5. L. W. Thomas, Smart Shoes, United States Patent, number: 5373651 (1994)

6. C. A. Vock, Y. Perry, Shoe wear-out sensor, body-bar sensing system, United States Patent, number: 7911339 (2008)

7. D. R. Carmo, M. Soares, F. A. Rocha, J.L. Carvalho, S.S Rodrigues, Insole with pressure control and tissue neoformation induction systems for diabetic foot, Conf Proc IEEE Eng Med Biol Soc , 51 (2010)

8. B. C. Braun, I. C. Roşca, I. Şerban, C. Cobliş, CAD Methods for Orthopedic Orthosis Prototyping, MediTECH 2, 388 - 391 (2011)

9. B. C. Braun, M. I. Baritz, I. C. Roşca, Research on the influence of progressive plantar supporters on the stability in biped position, OPTIROB 8, 465-470 (2013) 